\title{
Publisher Correction to: 0 Organism, Where Art Thou? Old and New Challenges for Organism-Centered Biology
}

\author{
Jan Baedke ${ }^{1}$
}

Published online: 12 August 2019

(c) Springer Nature B.V. 2019

\section{Correction to: Journal of the History of Biology (2019) 52(2):239-324 https://doi.org/10.1007/s10739-018-9549-4}

Please note that this article belongs to the Special Issue on "New Styles of Thought and Practices: Biology in the Interwar Period," guest editors Jan Baedke and Christina Brandt, but was included in volume 52, issue 2, Summer 2019 by mistake. It should be regarded as part of this special issue collection of articles.

Publisher's Note Springer Nature remains neutral with regard to jurisdictional claims in published maps and institutional affiliations.

The original article can be found online at https://doi.org/10.1007/s10739-018-9549-4.

Jan Baedke

jan.baedke@rub.de

1 Department of Philosophy I, Ruhr University Bochum, Universitätsstr. 150, 44801 Bochum, Germany 